\title{
E-PRIRUČNIK U NASTAVI STRANOGA JEZIKA STRUKE
}

\author{
Mirna Petanjek* \\ Ekonomski fakultet Sveučilišta u Zagrebu \\ Ankica Švob \\ Ekonomski fakultet Sveučilišta u Zagrebu
}

\begin{abstract}
Specifična organizacija nastave na preddiplomskom stručnom studiju stavlja pred nastavnike i studente brojne izazove. Studenti koji studiraju uz rad, intenzivna nastava, veličina i brojnost grupa te jezična nehomogenost grupa na kolegiju Početni njemački u poslovanju I najvažniji su problemi koje su autorice pokušale riješiti ili ublažiti izradom novoga e-priručnika i njegovom implementacijom u nastavi. U radu se predstavljaju načini na koje e-priručnik Deutsch im Geschäftsalltag 1 rješava probleme kolegija poslovnoga njemačkog jezika na početnom stupnju, posvećujući posebnu pozornost ujednačenosti kvalitete nastavnoga procesa u svim grupama. Novi e-priručnik u središte stavlja studenta kojemu omogućuje samostalni rad na postizanju ishoda kolegija, čime student ujedno preuzima odgovornost za proces učenja. E-priručnik ima i određene nedostatke koje je moguće prevladati osnivanjem e-kolegija koji bi se temeljio na novom e-priručniku.
\end{abstract}

Ključne riječi: stručni studij, e-priručnik, učenje usmjereno na studenta, samostalno upravljanje procesom učenja, ujednačenost kvalitete nastave.

\section{UVOD}

Pitanjem kako uspješnije poučavati i kako učinkovitije učiti u svojemu se radu bavi svaki nastavnik, a i svaki bi student želio biti što uspješniji u učenju. Odgovori na to pitanje omogućuju unaprjeđenje ne samo procesa poučavanja nego i procesa usvajanja znanja. Neprestano traganje za boljim metodama poučavanja primarni je zadatak svakog nastavnika jer je na taj način i studentu olakšano učenje. Mnogi se nastavnici pitaju, postoji li metoda poučavanja i učenja koja se može smatrati najboljom.

Budući da različito razmišljamo i da svatko na sebi svojstven način dolazi do zaključaka, isto tako individualno i učimo, tj. novo znanje usvajamo na različite načine (Kraft, 1999). Nastavnik također usvaja znanje na individualan način i stvara svoju biografiju učenja koja u velikoj mjeri utječe na njegovo poučavanje te ga čini subjektivnim i individualnim. Stoga je nemoguće naći najbolji način učenja i najbolju metodu poučavanja (Pfäffli, 2015).

\footnotetext{
* mpetanje1@net.efzg.hr

** asvob1@net.efzg.hr
} 
Jednako je tako vrlo teško izraditi udžbenik koji bi zadovoljio sve korisnike. Svaki autor udžbenika želi osmisliti udžbenik koji bi bio bolji od nekog prethodnog i na taj način ne samo olakšati usvajanje znanja, nego i unaprijediti načine poučavanja i učenja. Sama uporaba udžbenika u praksi pokazat će koliko je udžbenik, odnosno autor uspio u svome cilju. Opće odrednice koje autorima mogu pomoći da njihovo novo bude bolje od starog temelje se na osnovnim didaktičkim i metodičkim smjernicama poučavanja stranoga jezika (Meyer, 2003), na poznavanju temeljnih obilježja učenja i poučavanja, na spoznaji činjenice da je proces poučavanja i učenja individualan (Pfäffli, 2015) kao i na poznavanju problematike cijeloga studija i načina studiranja (Webler, 2005). Imajući sve te postavke u vidu, a posebno zbog činjenice da dobro poznajemo studij na kojem se predaje kolegij Početni njemački u poslovanju I odlučile smo doći do novih rješenja u nastavi njemačkoga poslovnog jezika na početnom stupnju koja bi dodatno motivirala studente, ali i nastavnike.

Kolegij poslovnoga njemačkog jezika obrađuje ekonomsku tematiku na početnom stupnju učenja njemačkoga jezika te ima svoje posebnosti s kojima se nastavnik i student suočavaju, koje pokušavaju prihvatiti i riješiti. U ovome radu navest ćemo razloge koji su nas potakli na objavu e-priručnika za kolegij Početni njemački u poslovanju I. Također ćemo prikazati kako novi priručnik rješava najvažnije probleme koje u našoj praksi nisu mogli riješiti dosadašnji udžbenici kojima smo se služile, kao i nove izazove koji su sada pred studentom i nastavnikom u radu s e-priručnikom. Predstavit ćemo i glavne smjernice kojima smo se rukovodile u nastajanju priručnika te ukazati na potencijal e-priručnika u okviru kolegija za koji je namijenjen.

\section{SPECIFIČNOSTI STRUČNOGA STUDIJA PRIKAZANE NA PRIMJERU KOLEGIJA POČETNI NJEMAČKI U POSLOVANJU I}

\subsection{Veličina i brojnost grupa}

Na prvoj godini Preddiplomskoga stručnog studija studenti upisuju dva obvezna strana jezika, poslovni engleski i poslovni njemački jezik. Nastavni program predviđa nastavu na dvije jezične razine, to jest, kolegije iz početnoga i naprednoga poslovnog engleskog i njemačkog jezika. Odabir početne ili napredne jezične razine temelji se na samoprocjeni znanja i slobodnome izboru svakoga studenta.

Zanimljiva je činjenica da velika većina studenata unatoč tome što imaju neko predznanje njemačkoga jezika odabire početnu razinu poslovnoga njemačkog jezika i upisuje kolegij Početni njemački u poslovanju I umjesto kolegij na naprednoj razini Njemački u poslovanju I. Slika 1 prikazuje broj upisanih studenata na oba kolegija. 


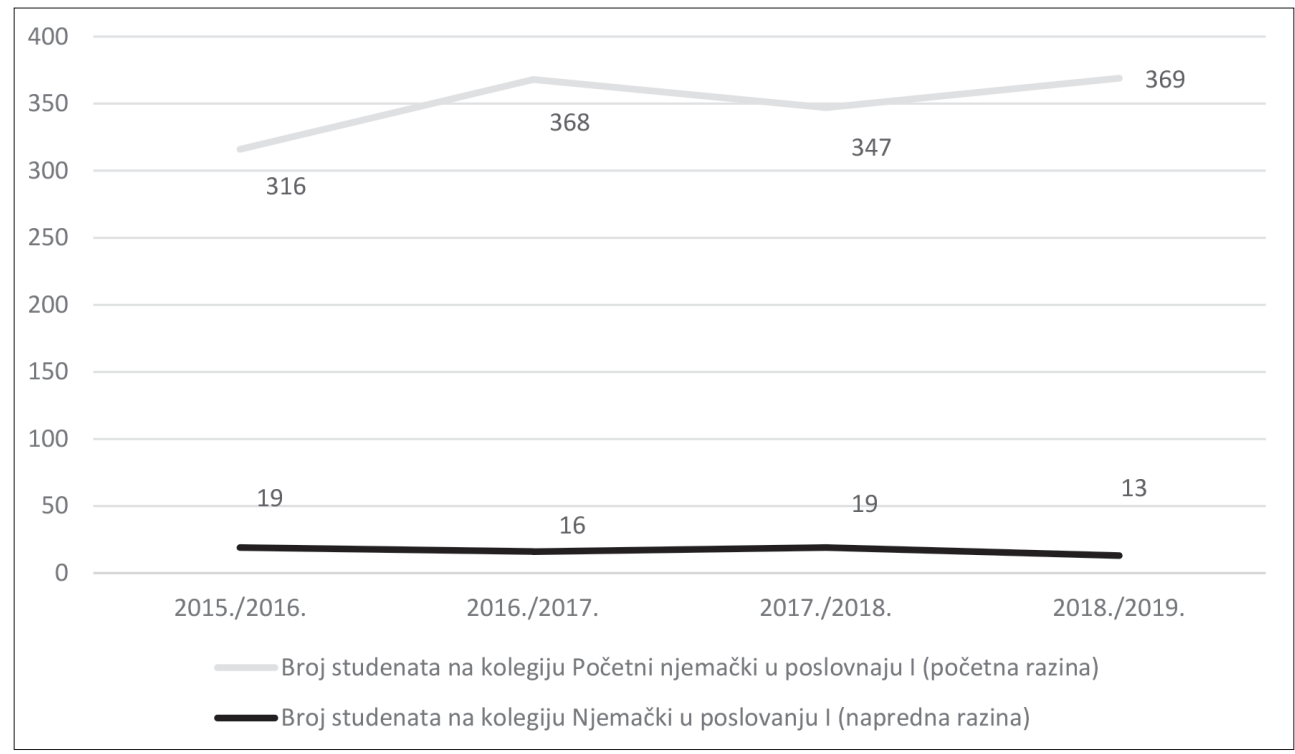

Slika 1. Broj upisanih studenata na kolegijima Početni njemački u poslovanju I $i$ Njemački u poslovanju I u razdoblju od ak. god. 2015./2016. do 2019./2020. na temelju podataka iz ISVU-a

Zbog takve se situacije na kolegiju Početni njemački u poslovanju I moraju organizirati grupe s velikim brojem studenata, što znatno otežava poučavanje stranoga jezika. Taj se problem može riješiti podjelom studenata u više grupa i angažiranjem dodatnih nastavnika (Wörner, 2008). U tablici 1 daje se prikaz broja upisanih studenata, broj grupa i prosječan broj studenata u grupi za kolegij Početni njemački u poslovanju I (PNJUP) u posljednjih pet akademskih godina.

Tablica 1. Broj upisanih studenata, broj grupa i prosječan broj studenata u grupi na kolegi$j u$ Početni njemački jezik u poslovanju I na temelju podataka iz ISVU-a

\begin{tabular}{|c|c|c|c|}
\hline \multicolumn{4}{|c|}{ POČETNI NJEMAČKI U POSLOVANJU I } \\
\hline ak. god. & $\begin{array}{c}\text { broj studenata na } \\
\text { kolegiju PNJUP I }\end{array}$ & broj grupa & $\begin{array}{c}\text { prosječan broj studenata } \\
\text { po grupi }\end{array}$ \\
\hline $2015 . / 2016$. & 316 & 4 & 79,0 \\
\hline $2016 . / 2017$. & 368 & 4 & 92,0 \\
\hline $2017 . / 2018$. & 347 & 4 & 86,75 \\
\hline $2018 . / 2019$. & 369 & 4 & 92,25 \\
\hline $2019 . / 2020$. & 657 & 6 & 109,5 \\
\hline
\end{tabular}

Zbog povećanja sveukupnog broja grupa i grupa s više od 100 studenata odlučile smo izraditi e-priručnik kojim smo željele osigurati kvalitetan nastavni proces u svim grupama bez obzira na njihovu veličinu, a koji pri tome nastavniku ne bi ograničio slobodu poučavanja kao ni studentu njegovu individualnost u učenju. 


\subsection{Studiranje uz rad (izvanredni studij)}

Sljedeća poteškoća koja utječe na sve sudionike nastavnoga procesa je način studiranja. Izvanredno studiranje ne obvezuje studente na pohađanje nastave, što u znatnoj mjeri otežava stjecanje svake vještine pa tako i jezične, osobito ako se radi o potpunim početnicima u predmetu.

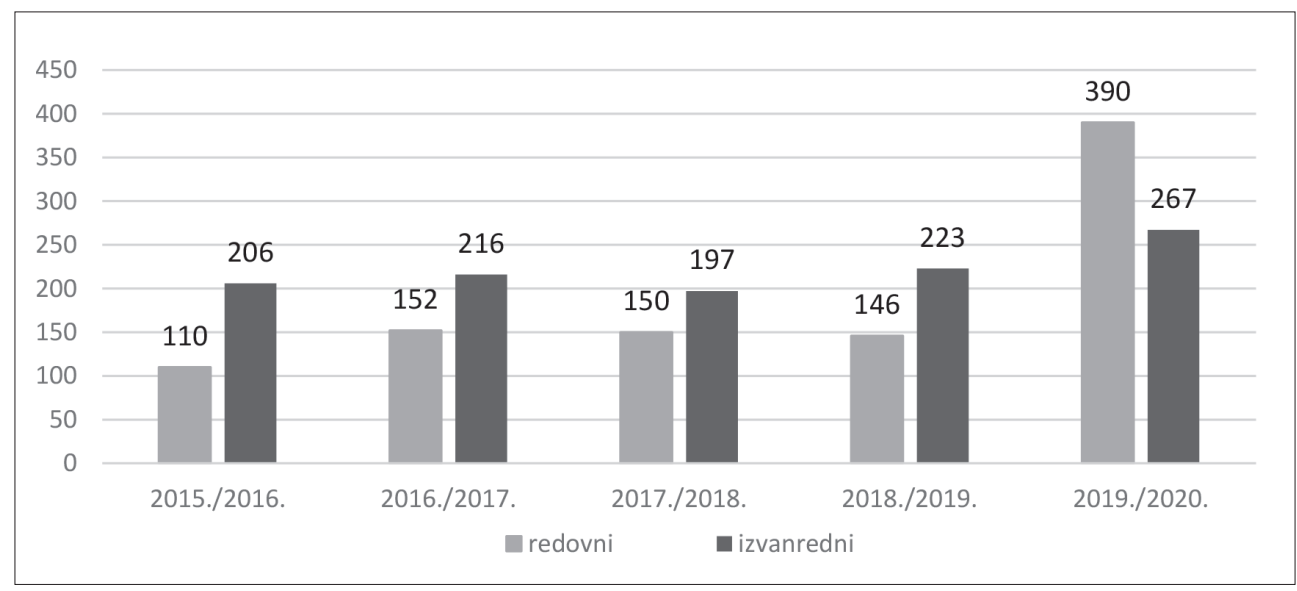

Slika 2. Broj redovnih i izvanrednih studenata na kolegiju Početni njemački u poslovanju I od 2015. do 2019. godine na temelju podataka iz ISVU-a

Slika 2 pokazuje da je na kolegiju Početni njemački u poslovanju I u razdoblju od 2015./2016. do 2019./2020. ak. god. bilo znatno više izvanrednih nego redovnih studenata. Izvanredni su studenti činili više od polovice sveukupnoga broja studenata koji su upisali taj kolegij. U akademskoj godini 2019./2020. broj je izvanrednih studenata nastavio rasti, iako je broj upisanih redovnih studenata sada veći od broja izvanrednih studenata.

Problem izvanrednih studenata koji nemaju obvezu dolaska na nastavu može se konzultacijama, tj. individualnim radom s pojedinim studentom, riješiti samo djelomično, pa je to bio još jedan razlog za izradu e-priručnika koji bi izvanrednim studenima mogao pomoći da lakše usvoje znanja i vještine poslovnoga njemačkog jezika na početnome stupnju.

\subsection{Organizacija nastave}

Organizacija nastave na stručnome studiju tijekom tri semestra, koliko ukupno traje nastava poslovnoga njemačkog jezika na stručnome studiju, ne omogućuje optimalnu nastavu, tj. usvajanje poslovnoga njemačkog jezika na početnoj razini. Naime, ukupan broj nastavnih sati provodi se u četiri bloka od šest sati nastave tijekom četiri tjedna. Šest sati nastave iz stranoga jezika s dvije stanke svakako predstavlja veliki izazov i za nastavnika i za studenta. E-priručnik može se smatrati podrškom u nastavi njemačkoga poslovnog 
jezika na početnoj razini jer studentima omogućuje samostalnost u učenju, ujedno održavajući zanimanje za usvajanje poslovnoga stranog jezika.

\subsection{Jezično nehomogene grupe}

Budući da ovaj kolegij upisuju i tzv. lažni početnici, tj. studenti koji su i prije upisa na stručni studij učili njemački jezik i stekli određena znanja, karakteristika je svih grupa jezična nehomogenost studenata. Ta je nehomogenost bitan čimbenik same nastave koji ju u znatnoj mjeri i otežava.

Prema iskustvima nastavnica brojni su razlozi zbog kojih velika većina studenata upisuje kolegij početne razine njemačkoga jezika iako su taj jezik učili tijekom prethodnoga školovanja. Mnogi smatraju da im je prethodno stečeno znanje nedovoljno za upis kolegija na višoj razini, neki ne mogu procijeniti svoje znanje, neki su nedovoljno informirani o sadržaju kolegija, a neki se vode željom da što lakše polože ispit. Samo manji broj studenata zaista su pravi početnici u učenju njemačkoga jezika, a zapravo je program ovoga kolegija namijenjen upravo njima. Rezultat su takvoga odabira grupe od stotinjak studenata s vrlo neujednačenom razinom znanja. Ta situacija rješava se smanjenjem obaveze prisutnosti na nastavi studentima koji imaju predznanje njemačkog jezika, ne ukidajući im pravo polaganja kolokvija.

Zadatak je e-priručnika stoga bio uskladiti različite ulazne jezične vještine i potencijale studenata, tj. na jednak način svima omogućiti napredak na kolegiju.

\section{E-PRIRUČNIK „DEUTSCH IM GESCHÄFTSALLTAG 1 FÜR ANFÄNGER. HANDBUCH UND ÜBUNGSBUCH MIT DEM LÖSUNGSTEIL"}

Na početku izrade novoga udžbenika uvijek je potrebno razmotriti ciljeve i ishode učenja na visokoškolskoj razini (Pfäffli, 2015) te ih ugraditi u novi udžbenik. Na tim osnovama i uzimajući u obzir specifičnosti načina učenja i poučavanja poslovnoga njemačkog jezika na stručnome studiju pri izradi e-priručnika postavljeni su sljedeći ciljevi koje bi e-priručnik trebao ispuniti:

- uočiti važnost poslovnoga njemačkog jezika u društvu i gospodarstvu

- osposobiti studenta za osnovnu poslovnu komunikaciju na njemačkome jeziku

- razviti sociokulturne vještine potrebne u poslovnim situacijama

- osvijestiti važnost samostalnoga upravljanja procesom učenja

- razviti interes za daljnje učenje poslovnoga njemačkog jezika

Pojmovi uočiti, osposobiti i razviti navedeni u ciljevima uključeni su u program kolegija Početni njemački u poslovanju I, ali u izvedbi nastave dolazi do poteškoća koje onemogućavaju ispunjavanje postavljenih ciljeva. Stoga je bilo potrebno naći nova rješenja. Smatramo da e-priručnik može pomoći 
i studentu i nastavniku da se približi ostvarenju navedenih ciljeva i ishoda poučavanja.

\subsection{Struktura e-priručnika}

U uvodnom dijelu e-priručnika navedeni su ciljevi kolegija i ciljna skupina. Slijede objašnjenja i upute koje studentima pojašnjavaju upotrebu priručnika te popis tematskih cjelina. Na početku svakejezične cjeline navedeni su ishodi učenja. Novi jezični materijal pojedinih cjelina prezentiran je postupno, pregledno i jasno, s prijevodom na hrvatski jezik kao i s uputama za izgovor. Načela postupnosti, jasnoće i preglednosti slijede i zadaci za uvježbavanje jezičnoga gradiva jer se uvježbava od jednostavnijih prema složenijima (Brinitzer i sur., 2013), a svaka nova riječ prevedena je na hrvatski jezik. Na kraju svake tematske podcjeline nalaze se rješenja zadataka, a svaka od četiri cjeline završava i oglednim zadacima za pismenu provjeru znanja (kolokvij). Na kraju priručnika nalaze se mali fonetski rječnik, abecedni rječnik, popis udžbenika i rječnika koji studentima mogu olakšati rad te popis mobilnih aplikacija kao i poveznice na video zapise (Fischer, Mandl i Todorova, 2009) koji se preporučuju za samostalno učenje njemačkoga jezika. E-priručnik je prilagođen radu putem mobitela i računala te je u svakom trenutku dostupan studentu.

\subsection{Doprinos e-priručnika ostvarenju ciljeva kolegija}

Kao prvi veći problem ovoga kolegija naveden je rad u velikim grupama s nešto više od sto studenata. Rad u velikim grupama svakako dovodi u pitanje osiguranje standarda kvalitete nastave, odnosno ostvarenje postavljenih ciljeva i ishoda kolegija, obradu svih izabranih nastavnih sadržaja, te procjenu rada nastavnika (Pfäffli, 2015) kao i stečenih znanja i kompetencija studenata (Metz-Göckel, Kamphans i Scholkmann, 2012).

Svi sudionici nastavnoga procesa trebaju ponajprije težiti ostvarenju istih ciljeva i ishoda učenja (Gutting, 2003). Rad svih studenata i njihova nastavnika na postizanju zajedničkih ciljeva preduvjet je za potrebnu ujednačenost. Iznimno je važno da postavljeni ciljevi i ishodi učenja kolegija budu jasno formulirani i razumljivi, stoga ih nastavnik na početku nastave treba objasniti i o njima porazgovarati sa studentima (Sembill i Seifried, 2006). Zbog toga je i e-priručnik tako osmišljen da studente i nastavnike jasno vodi do postizanja navedenih ciljeva $\mathrm{i}$ ishoda kako bi time osigurao potrebnu ujednačenost kvalitete nastavnoga procesa.

Ciljevi kolegija Početni njemački u poslovanju I navedeni su u uvodnome dijelu e-priručnika, dok se ishodi učenja nalaze na početku svake nastavne cjeline. Slika 3 prikazuje navode ishoda učenja na početku četvrte cjeline. 


\section{EINHEIT 4 / CJELINA 4}

Na kraju ove cjeline moći ćete pobliže predstaviti zaposlenike poduzeća, pregovarati s kupcima, prepoznati probleme poduzeća i predložiti načine njihova rješavanja.

Slika 3. Primjer ishoda učenja na početku cjeline 4 u e-priručniku Deutsch im Geschäftsalltag 1

Osim jasno postavljenih ciljeva i ishoda učenja, ujednačenost kvalitete nastavnoga procesa osigurava i način prezentacije jezičnoga materijala $u$ e-priručniku. U prve dvije cjeline novo se gradivo uvodi izvan konteksta $u$ obliku rečenica, fraza i izraza s prijevodom na hrvatski jezik te potrebnim uputama i pravilima. U kasnijim zadacima novi jezični materijal dolazi u situacijskom okviru. Taj način prezentiranja gradiva u prve dvije cjeline e-priručnika prikazan na slici 4 razlikuje se od onoga u udžbenicima po kojima se do sada poučavalo.

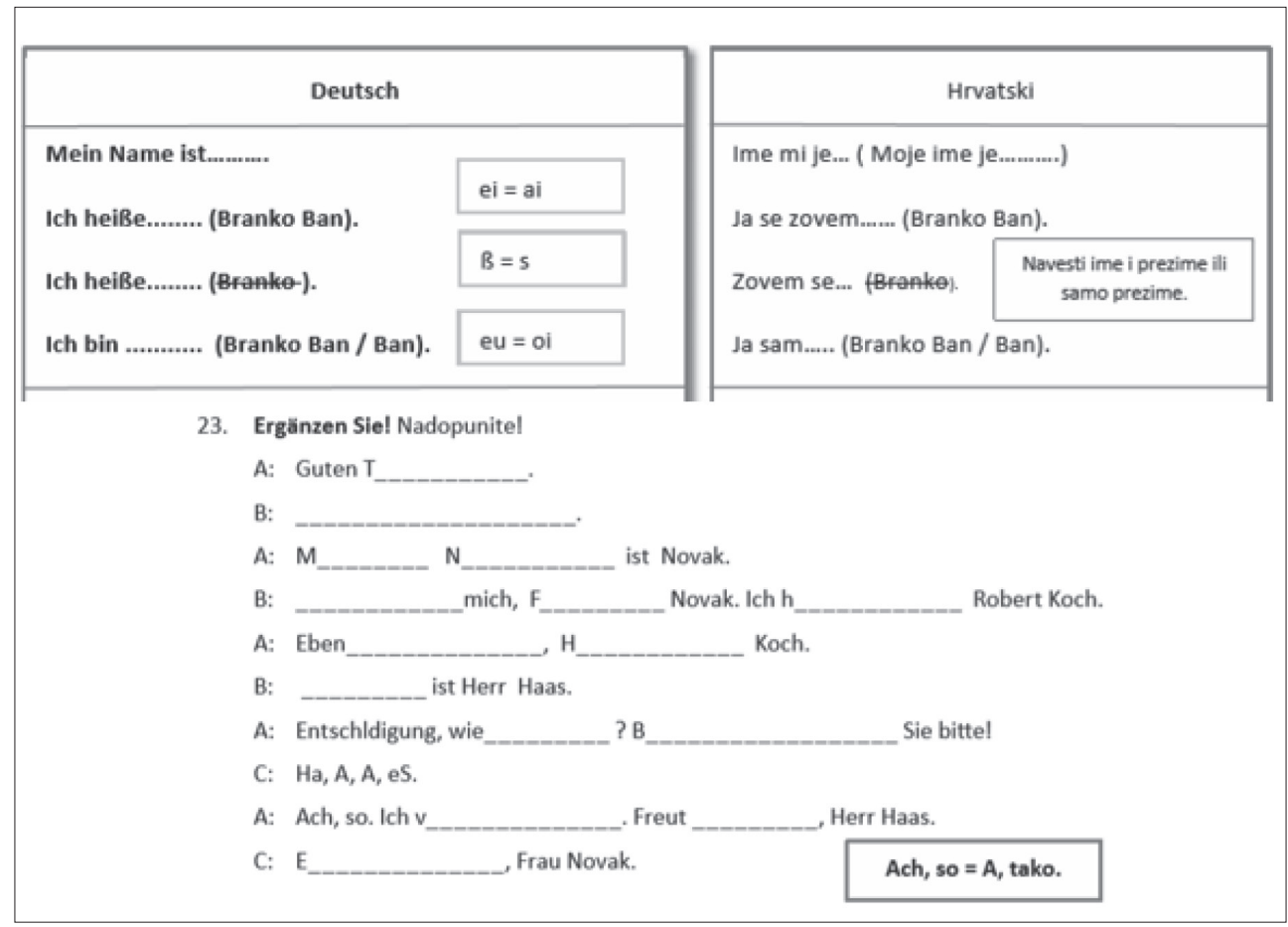

Slika 4. Primjer prikaza novoga jezičnog sadržaja i zadatka u situacijskom kontekstu u e-priručniku Deutsch im Geschäftsalltag 1

U dosadašnjim jezičnim udžbenicima cjeline započinju kontekstom (dijalog ili narativni tekst) koji se kasnije analizira i uvježbava. Takav način studentu otežava samostalno snalaženje, razumijevanje i učenje, te ga čini ovisnim o nastavniku (Seidel i Hoppert, 2011). Uobičajeni pristup 
prezentaciji jezičnoga materijala (kontekst pa zatim analiza s vježbama) stavlja nastavnika u središte procesa poučavanja. Stoga e-priručnik svojom koncepcijom, u čijem je središtu student, čini upravo suprotno jer na taj način studentu omogućuje samostalno učenje.

Opisani način prezentacije novoga gradiva zadržava se i u trećoj i četvrtoj cjelini, kada se uvode narativni tekstovi i dijalozi nakon kojih slijede zadaci. Tekstovi se uvode tako da se svaka rečenica odmah prevodi na hrvatski jezik s navodom novih riječi i izraza, a sadržaji koji slijede smisleno i vokabularno međusobno se nadopunjuju i proširuju, kao što je prikazano na slici 5.

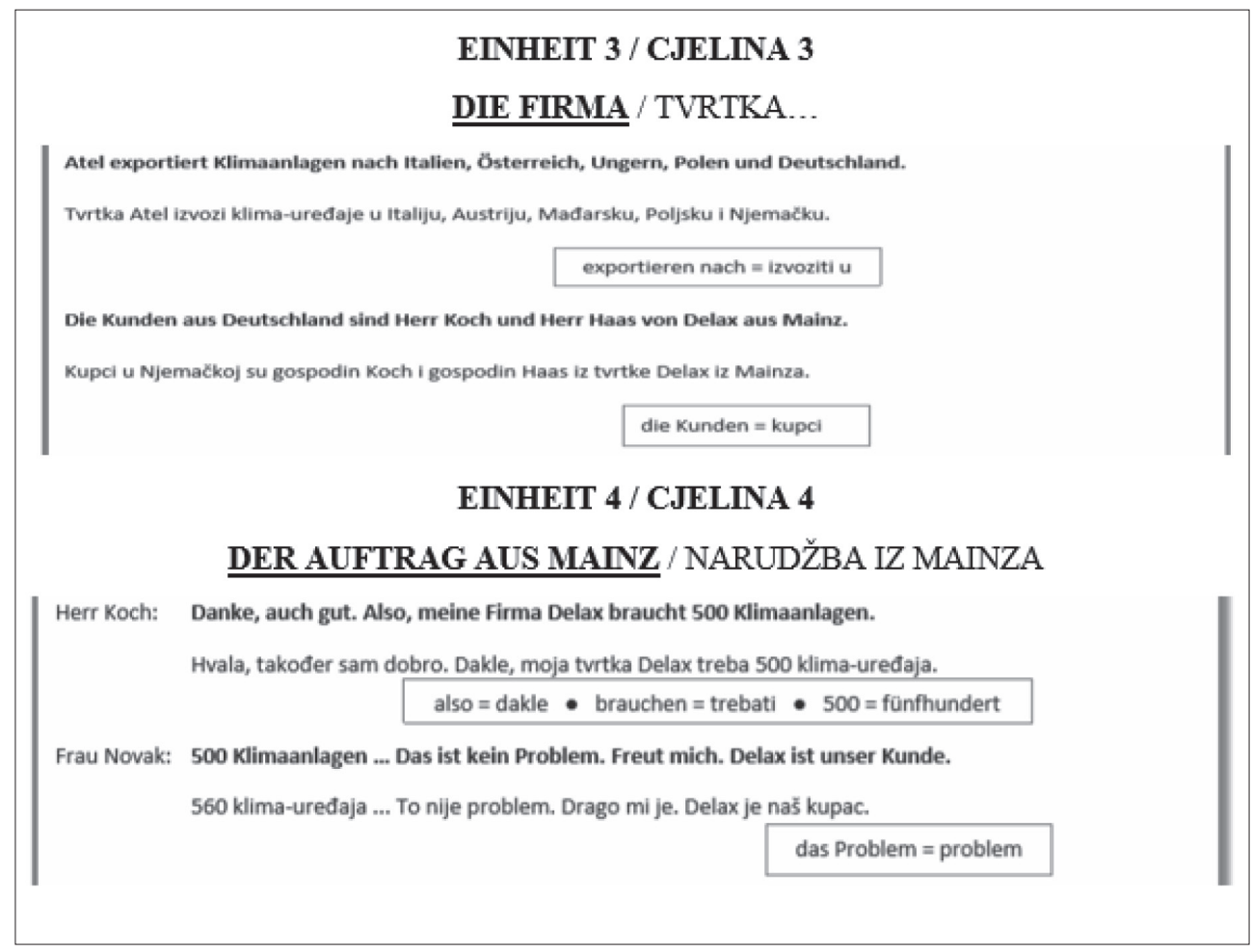

Slika 5. Primjeri narationog teksta i dijaloga iz treće i četorte cjeline e-priručnika Deutsch im Geschäftsalltag 1

Iz gornjega je prikaza vidljivo da način na koji je gradivo u priručniku prezentirano osigurava da studenti mogu samostalno učiti te im istovremeno omogućuje usvajanje propisane jezične razine, pa tako postaje jezičnim standardom za sve studente. E-priručnik ujedno postavlja i standard za sve nastavnike koji predaju ovaj kolegij, što omogućuje osiguranje kvalitete nastavnog procesa kolegija. Prikaz primjera zadataka za kolokvij pokazuje kako e-priručnik odgovara na zahtjev ispunjenja standarda.

$\mathrm{Na}$ kraju svake nastavne cjeline nalaze se, dakle, primjeri zadataka za pismenu provjeru znanja (kolokvij). Ti primjeri uključuju ispitno gradivo te 
su zbog jasno postavljenih kriterija ocjenjivanja (broj bodova i pripadajuća ocjena) kontrolne točke i orijentir za sve sudionike nastavnoga procesa. Dio drugoga primjera pismene provjere znanja prikazan je na slici 6 .

\section{PRÖFUNGSBEISPIEL 2 / PRIMJER PISMENOG KOLOKVIJA 2}

2. Ist der Satz falsch oder richtig? Kreuzen Sie an! Je II ređenica netoz̄na ill toŽna? OrnaEite!
a) Sie entschuldigen bitte!
falsch / richtig
b) Woher Frau Novak kommt?
falsch / richtig.
c) Sind Sie von Bosch?
falseh $/$ richtig
d) Kommt aus Zadar Herr Krolo?
falsch / richtig
e) Frau und Herr Schulz wohnen in Wien.
falsch / richtig
f) Frau Gubo um 8.00 kommt nach Zagreb.
falsch / richtig

(6)

3. Schreiben Sie die falschen Sätze aus der Aufgabe 4 richtig! Napiß̇ite netoc̄ne rečenice iz vjeżbe 4 ispravno!

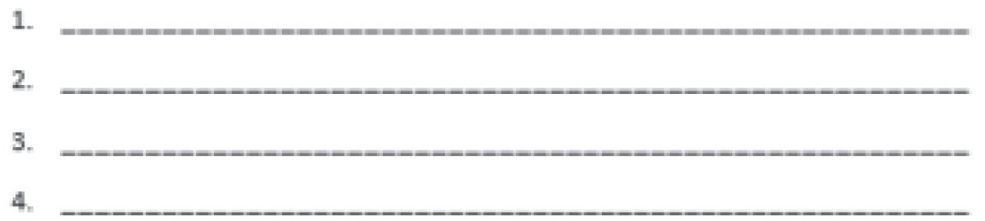

$$
\begin{aligned}
59 \text { bodova } \rightarrow & 6 \text { pogrejaka }=\text { izvrstan (5) } \quad 12 \text { pogrejaka = vrlo dobar (4) } \\
& 18 \text { pogrejaka }=\text { dobar (3) } \quad 24 \text { pogreßke = dovoljan (2) }
\end{aligned}
$$

Lōsungsteil / Rješenja

Einheit 2 - Prüfungsbeispiel 2

2. a) falsch b] falsch c] richtig d) falsch e) richtig f] falsch

3. 1) Entochuldigen sie bitte! 2) Woher kommt Frau Novak? 3) Kommt Herr Krolo aus Zadar?

4. Frau Gubo kommt um 8:00 Uhr nach Zagreb.

Slika 6. Zadaci iz primjera zadataka za kolokvij s rješenjima iz e-priručnika Deutsch im Geschäftsalltag 1

Dakle, ogledni primjeri pismenih kolokvija predstavljaju normu potrebnoga znanja ne samo studentima nego i nastavnicima. Prihvaćanjem modela kolokvija kao standarda znanja za sve, e-priručnik u velikoj mjeri doprinosi ujednačenosti kvalitete nastavnoga procesa. 
Studiranje uz rad drugi je problem ovoga kolegija. Učenje stranoga jezika i usvajanje jezične vještine bez obveze pohađanja nastave velika je prepreka studentu u postizanju zadanih ciljeva i ishoda učenja.

Kako bi mogao pomoći studentima koji studiraju uz rad, priručnik mora $\mathrm{u}$ velikoj mjeri preuzeti ulogu nastavnika, stoga mu struktura mora biti jasna i pregledna, a gradivo se mora obraditi postupno. Koncepcija priručnika, opisana u točki 3.1., svakako omogućuje studentu samostalno učenje te se iz prikaza e-priručnika vidi da je student u središtu poučavanja. Struktura e-priručnika potiče studenta na aktivnost tijekom procesa učenja, pomaže mu razumjeti i usvojiti gradivo, uvježbati gradivo te ga povezati s već naučenim i, konačno, samostalno provjeriti svoje znanje te na taj način preuzeti odgovornost za proces učenja (Kraft, 1999). Studenti koji studiraju uz rad svjesni su važnosti stranoga jezika u poslovnom okruženju te pokazuju interes za usvajanje poslovnoga stranog jezika jer ga na svojemu radnom mjestu mogu odmah primijeniti. Zbog toga je iznimno važno da jezično gradivo kao i sve vježbe budu takve da ih studenti mogu savladati, a odabrani jezični materijal u potpunosti primjenljiv u poslovnoj praksi.

Osim opisanih prednosti, e-priručnik ima i svoje manjkavosti. Kao tiskani medij nedostatan je za usvajanje pravilnoga izgovora, stoga je potrebno dodatno se koristiti elektroničkim medijima s video i audio zapisima. Video i audio zapisi mogu studentima koji rijetko imaju priliku učiti izgovor od nastavnika pomoći da savladaju pravilni izgovor njemačkih glasova. Zbog toga e-priručnik preporučuje besplatne mobilne aplikacije za učenje njemačkoga jezika kao i video uratke na YouTubeu koji odgovaraju jezičnom stupnju kolegija.

Sljedeći je nedostatak opasnost da se student $u$ radu s e-priručnikom zatvori u vlastitu samodostatnost. Nastavnik treba prepoznati tu mogućnost te studenta izvući iz vlastite izolacije. Studenta treba potaknuti na zajednički razgovor o sadržaju i organizaciji kolegija, bilo elektroničkom poštom ili konzultacijama, te ga uputiti na razmjenu iskustava i radnih materijala $\mathrm{s}$ kolegama (Brinitzer i sur., 2013). Razgovori i izmjena iskustava s kolegama i nastavnikom na društvenim grupama, osobito danas, neizostavan su način stjecanja, proširivanja i utvrđivanja znanja (Brinitzer i sur., 2013). Stoga su i neizostavna nadopuna e-priručniku. Velik broj studenata koristi se elektroničkim izvorima znanja. Smatramo da e-priručnik studentu koji studira uz rad pruža mogućnost usvajanja znanja, ali interakcija među studentima (Pfäffli, 2015.) i s ostalim sudionicima nastavnoga procesa (Kraft, 1999) ne smije izostati.

Organizacija nastave sljedeći je problem stručnoga studija (četiri dolaska raspoređena tijekom četiri tjedna s po šest sati nastave) čije rješavanje zahtijeva i od nastavnika i od studenata veliki napor. Svi se sudionici $u$ takvoj koncepciji nastave bore sa zamorom kao i s padom koncentracije. 
Izvođenje nastave $\mathrm{u}$ takvim okolnostima traži veliku metodičku vještinu nastavnika. No, činjenica da svi studenti trebaju i mogu tijekom jednoga dolaska u potpunosti savladati jezični standard propisan primjerom provjere znanja, rasteretit će donekle nastavnika. Naime, tako koncipiran e-priručnik omogućit će studentima da sve ono što su propustili tijekom nastave, bilo zbog zamora, pada koncentracije ili jednostavno nezainteresiranosti, nadoknade i provjere samostalnim radom (Kopp i Mandl, 2011) kod kuće ili u razgovoru s kolegama i nastavnikom izvan nastave.

Organizacija nastave stručnoga studija pred nastavnika stavlja još jedan izazov. Budući da se početni poslovni njemački jezik nastavlja učiti i u sljedeća dva semestra, važno je održati motivaciju i interes studenata za daljnje usvajanje poslovnoga njemačkog jezika (Pfäffli, 2015). Jedinstveni recept za postizanje motivacije ne postoji, dakle, ne postoje upute čija primjena nastavniku osigurava motiviranu grupu studenata. Prema Wörneru (2008) motivaciju treba razumjeti kao otvorenost studenta prema učenju, odnosno u našemu slučaju, kao spremnost studenta za usvajanje poslovnoga njemačkog jezika, koju treba pažljivo njegovati i pri tome ne dopustiti da je pregazi kumulativna i zahtjevna nastava. Stoga nastavnik može prema vlastitoj prosudbi napraviti izbor nastavnih sadržaja iz priručnika, izostaviti pojedine vježbe, uvrstiti u nastavu dodatne materijale $s$ vježbama, no pri tome mora dobro paziti da svojim odabirom dodatno ne optereti studente i tako ih obeshrabri za daljnje učenje poslovnoga njemačkog jezika (Fischer i sur., 2009). Treba naglasiti da se gubitkom interesa za daljnje učenje ne ostvaruje jedan od navedenih ciljeva kolegija. Nastavnik, dakle, mora dobro poznavati sadržaj kolegija, imati osjećaj za duljinu trajanja pauza i pojedinih nastavnih segmenata u tijeku nastavnoga procesa te biti svjestan činjenice da je nastava studentima intenzivna i naporna (Brinitzer i sur., 2013). E-priručnik mu propisanim gradivom koje se ispituje kolokvijima pomaže u odabiru i određivanju opsega jezičnoga materijala ovoga nastavnog koncepta.

Veliki problem također predstavlja i nehomogenost jezičnih grupa. Zadatak je nastavnika pronaći ispravan način poučavanja kojim će motivirati sve studente. Kao što se iz slike 1 može uočiti, samo je vrlo malen broj studenata pravih početnika u učenju njemačkoga jezika, a njima je kolegij Početni njemački u poslovanju I zapravo namijenjen. Potpuni su početnici za nastavnika ovoga kolegija najzahvalnija populacija, jer su im očekivanja i interes za učenje novoga stranog jezika veliki. Svi ostali studenti dolaze s različitim iskustvima koja određuju njihov odnos prema njemačkome jeziku. Studente koji su učili njemački više godina, a koji su upisali Početni njemački u poslovanju I, pokreću različiti motivi (vidi točku 2.4.). Toj je skupini potrebno naglasiti da se tijekom ovoga kolegija usvaja poslovni njemački jezik primjenljiv u poslovnoj praksi i da će unatoč početnoj jezičnoj razini kolegija 
usvojiti nove poslovne sociokulturne i komunikacijske vještine. Napredne bi studente trebalo potaknuti na samostalni rad koji ovaj e-priručnik omogućuje.

Radom na e-priručniku studenti mogu i samovrednovati novo naučeni stručni vokabular s gramatikom kao i svoje poznavanje pravila ponašanja u poslovnome svijetu. Predznanja koja studenti imaju daju im mogućnost da samostalno upravljaju procesom učenja. Prema Pfäffli (2015) student je aktivni sudionik procesa, on samostalno donosi odluke što, kada, kako i s kojom svrhom učiti. Služeći se e-priručnikom studenti s predznanjem mogu sami donositi odluke te vrste. Mogu preskočiti gradivo koje već znaju te samostalno izabrati i uvježbati jezični materijal koji žele ili moraju usvojiti (Kraft, 1999). Time preuzimaju velik dio odgovornosti za vlastitu uspješnost u usvajanju ishoda učenja, što može motivirati velik broj studenata (Messner, Niggli i Reusser, 2009). Osim toga, činjenica da je e-priručnik uvijek elektronički dostupan, njegova je velika prednost. Naravno da je bez interesa i želje studenta za ovladavanjem poslovnoga njemačkog jezika teže ostvariti planirane ishode učenja (Kopp i Mandel, 2011). Dakle, motivacija i interes za proširenjem znanja poslovnim vokabularom i kod naprednih studenata igraju veliku ulogu. Nastavnik bi to trebao uzeti u obzir i pobrinuti se da takvi studenti svoje znanje njemačkoga jezika ponove i utvrde, ali i prošire poslovnim vokabularom tako što će ih uputiti na popis internetskih stranica i mobilnih aplikacija (Messner i sur., 2009). Na taj će način studenti upotpuniti i obogatiti svoje znanje poslovnoga njemačkog jezika. Takav pristup studentima s predznanjem mogao bi razviti i održati njihov interes za nastavak učenja poslovnoga njemačkog jezika.

\section{BUDUĆNOST E-PRIRUČNIKA}

Na kolegijima Početni njemački u poslovanju II i Početni njemački u poslovanju III, koji se održavaju u sljedeća dva semestra, nastavnici i studenti suočavaju se $\mathrm{s}$ istim poteškoćama $\mathrm{u}$ nastavi, pa bi se i na tim kolegijima mogao uvesti e-priručnik. O tome će odlučiti svi sudionici nastavnoga procesa istraživanjem o uspješnosti prvoga e-priručnika. Studenti će također ocijeniti koliko su nastavnici bili uspješni u implementaciji prvoga e-priručnika.

E-priručnik se svakako može dalje unaprjeđivati. Nove tehnologije nude različita rješenja. Jedno je od njih i mogućnost pokretanja e-kolegija koji bi se temeljio na e-priručniku. U okviru e-kolegija koji pruža mnogo veće mogućnosti (Pfäffli, 2015), e-priručnik svakako bi se mogao unaprijediti i obogatiti, a njegova primjena proširiti. Stoga e-priručnik potencijale može zaista najbolje ostvariti u okviru e-kolegija (Huber, 1999). 


\section{ZAKLJUČAK}

E-priručnik Deutsch im Geschäftsalltag 1 für Anfänger. Handbuch und Übungsbuch mit dem Lösungsteil koji prati kolegij Početni njemački u poslovanju I namijenjen je studentima preddiplomskoga stručnog studija Poslovne ekonomije.

Može se zaključiti da:

1. e-priručnik s jasno postavljenim ciljevima i ishodima učenja kao i svojom koncepcijom koja predstavlja standard za usvajanje i provjeru znanja za sve sudionike $u$ velikoj mjeri može doprinijeti da se postigne ujednačena kvaliteta nastavnoga procesa u velikim grupama.

2. e-priručnik u svom središtu ima studenta. Svojom preglednošću i postupnošću studentima, a pogotovo onima koji studiraju uz rad omogućuje i osigurava samostalni rad te im tako pomaže u preuzimanju odgovornosti u procesu učenja.

3. e-priručnik, jasno definirajući opseg gradiva primjerima provjere znanja, omogućuje studentima da sve propušteno tijekom nastave nadoknade samostalnim radom i tako ublaže negativne posljedice organizacije nastave na stručnome studiju.

4. e-priručnik studentima s predznanjem omogućava samostalno upravljanje procesom učenja. Studenti sami donose odluke što, kada i kako ponoviti te verificirati naučeno ili usvojiti novo jezično gradivo. Ta odlika priručnika može motivirati napredne studente na daljnje učenje, ali i pomoći u rješavanju problema jezične nehomogenosti grupa na stručnome studiju.

5. e-priručnik uvijek je dostupan i omogućuje učenje u raznim situacijama.

Analiza priručnika ukazuje i na njegove nedostatke:

1. Kao pisani medij e-priručnik je nedostatan za pravilno usvajanje izgovora. Ta se manjkavost može riješiti uporabom elektroničkih i audiovizualnih medija u procesu učenja.

2. Budući da e-priručnik izvanrednim studentima osigurava samostalan rad, postoji opasnost njihove izolacije tijekom rada s priručnikom, stoga te studente treba uputiti na potrebnu interakciju s kolegama i nastavnikom.

3. Na prvi pogled jezično se gradivo e-priručnika studentima s predznanjem njemačkoga jezika može činiti prejednostavnim, pa te studente treba usmjeriti na usvajanje novoga poslovnog vokabulara pomoću preporučenih dodatnih materijala.

4. Svojom koncepcijom, osobito u prvim dvjema lekcijama, e-priručnik može nastavniku otežati poučavanje jer je način prezentacije gradiva $u$ prvome redu prilagođen studentu.

E-priručnik predstavlja dobru osnovu za rad na razvoju budućega e-kolegija Početni njemački u poslovanju I koji bi svojom bogatom paletom različitih mogućnosti istaknuo prednosti priručnika, umanjio njegove manjkavosti te ga na taj način nadopunio i proširio. 


\section{LITERATURA}

Brinitzer, M., Hantschel, H. J., Kroemer, S., Möller-Frorath i M., Ros, L. (2013) DaF unterrichten: Basiswissen Didaktik - Deutsch als Fremd- und Zweitsprache. Stuttgart: Klett Sprachen.

Fischer, F., Mandl, H. i Todorova, A. (2009) Lehren und Lernen mit neuen Medien. U Tippelt, R. i Schmidt, B. (ur.) Handbuch Bildungsforschung. Wiesbaden: VS Verlag für Sozialwissenschaften, 753-771. https://link.springer.com/chapter/10.1007/978-3-531-91831-0_40 (12. 12. 2019.)

Gutting, B. (2003) Gruppenpädagigik und Kommunikation. Mainz: Syntact Gesellschaft für Bildung, Bratung und Service mbH im Auftrag der Katholischen Erwachsenenbildung Rheinland-Pfalz, Landesarbeitsgemeinschaft e.V. https://www.yumpu.com/de/document/read/5602082/gruppenpadagogik-und-kommunikation-fernkurs-heilpaedagogik (12. 12. 2019.)

Huber, L. (1999) An- und Aussichten der Hochschuldidaktik. Zeitschrift für Pädagogik 45 (1), $25-45$. https://www.pedocs.de/volltexte/2012/5937/pdf/ZfPaed_1999_1_Huber_Hochschuldidaktik. pdf (12. 12. 2019.)

Kopp, B. i Mandl, H. (2011) Selbstgesteuertes Lernen. Enzyklopädie Erziehungswissenschaft Online., 1-33 https://www.researchgate.net/publication/304621698_Selbstgesteuertes_Lernen (12. 12. 2019.)

Kraft, S. (1999) Selbstgesteuertes Lernen. Problembereiche in Theorie und Praxis. Zeitschrift für Pädagogik 45 (6), 833-845. https://www.pedocs.de/volltexte/2012/5979/pdf/ZfPaed_1999_6_Kraft_ Selbstgesteuertes_Lernen.pdf (15. 12. 2019.)

Messner, H., Niggli, A. i Reusser, K. (2009) Hochschule als Ort des Selbststudiums. Spielräume für selbstgesteuertes Lernen. Beiträge zur Lehrerinnen- und Lehrerbildung 27 (2), 149-162. https:// www.pedocs.de/volltexte/2017/13716/pdf/BZL_2009_2_149_162.pdf (15. 12. 2019.)

Metz-Göckel, S., Kamphans, M. i Scholkmann, A. (2012) Hochschuldidaktische Forschung zur Lehrqualität und Lernwirksamkeit. Zeitschrift für Erziehungswissenschaft 15 (2), 213-232. https:// www.researchgate.net/publication/270585194_Hochschuldidaktische_Forschung_zur_Lehrqualitat_und_Lernwirksamkeit (15. 12. 2019.)

Meyer, H. (2003) Zehn Merkmale guten Unterrichts, Pädagogik 10/03, 36-43. http://boden.fdbio-tukl.de/assets/files/fd_documents/evaluation_kriterien/976_9_0_10MerkmalegutenUnterrichts.pdf (15. 12. 2019.)

Petanjek, M. i Švob, A. (2019) Deutsch im Geschäftsalltag 1 für Anfänger. Handbuch und Übungsbuch mit dem Übungsteil. /Njemački u poslovnoj svakodnevici 1 za početnike. Priručnik s vježbenicom $i$ rješenjima. Zagreb: Ekonomski fakultet Sveučilišta u Zagrebu. https://www.efzg.unizg.hr/UserDocsImages/KID/Prirucnik\%20e\%20izdanje.pdf

Pfäffli, B. K. (2015) Lehren an Hochschulen. Eine Hochschuldidaktik für den Aufbau von Wissen und Kompetenzen. Stuttgart: UTB GmbH.

Seidel T. i Hoppert, A. (2011) Merkmale von Lehre an der Hochschule. Unterrichtswissenschaft 2, 154-172. https://www.researchgate.net/publication/256655681_Merkmale_von_Lehre_an_ der_Hochschule_Ergebnisse_zur_Gestaltung_von_Hochschulseminaren_mittels_Videoanalysen (15. 12. 2019.)

Sembill, D. i Seifried, J. (2006) Selbstorganisiertes Lernen als didaktische Lehr-Lern-Konzeption zur Verknüpfung von selbstgesteuertem und kooperativem Lernen. Selbst gesteuertes Lernen in der beruflichen Bildung, 93-108. https://kops.uni-konstanz.de/bitstream/handle/123456789/11957/ Seifried_2006_Selbstorganisisertes_Lernen_als_didaktische_Lehr_Lern_Konzeption.pdf?sequence=1\&isAllowed=y (15. 12. 2019.)

Webler, W.-D. (2005) „Gebt den Studierenden ihr Studium zurück!“ Über Selbststudium, optimierende Lernstrategien und autonomes Lernen (in Gruppen). Beiträge zur Lehrerinnen- und Lehrerbildung 23 (1), 22-34. https://www.pedocs.de/volltexte/2017/13560/pdf/BZL_2005_1_22_34. pdf (15. 12. 2019.)

Wörner, A. (2008) Lehren an der Hochschule. Eine praxisbezogene Anleitung. Wiesbaden: VS Verlag für Sozialwissenschaften. 


\section{E-HANDBOOK IN TEACHING A FOREIGN LAGUAGE FOR SPECIFIC PURPOSES}

The organization of classes of the undergraduate professional study presents a challenge to both the teachers and students. An attempt has been made by the teachers to solve, or at least alleviate, the issues of running intensive courses for part-time students, working in large and numerous groups and dealing with mixed-ability groups of students who take the Business German for Beginners 1 course by developing and implementing a new e-handbook. The paper presents the e-handbook German for Everyday Business I and the way it tackles these issues in the German business course for beginners, paying special attention to the aim of achieving equal quality of teaching in all groups. The new e-handbook focuses on the student. It enables the student to study independently and to achieve the course outcomes, which means that the student takes the responsibility for the learning process. However, the e-handbook has some disadvantages, which can be overcome by an e-course to be designed on the basis of this e-handbook.

Keywords: professional study, e-handbook, student-centred approach, self-regulated learning, quality of teaching.

This work is licensed under a Creative Commons Attribution 4.0 International License.

Ovaj rad dostupan je za upotrebu pod licencom Creative Commons Imenovanje 4.0 međunarodna. 